\title{
Death during recovery from severe malnutrition and its possible relationship to sodium pump activity in the leucocyte
}

\author{
JOHN PATRICK
}

British Medical fournal, 1977, 1, 1051-1054

\section{Summary}

The leucocyte data on four malnourished children who died suddenly when high-energy feeding was started were retrospectively analysed. The pretreatment rate constant for sodium efflux in leucocytes was higher and the intracellular sodium concentration lower in this group than in 13 malnourished children who recovered uneventfully with feeding. Two other children with unusual leucocyte electrolyte values and sodium pump activity were identified and closely monitored when high-energy treatment was begun. They rapidly developed the syndrome of extracellular fluid overload but were successfully treated with diuretics and digoxin. Though the precise relation between the findings in the leucocytes and the development of this overload syndrome is not clear, the pretreatment leucocyte values are nevertheless valuable in predicting which malnourished children are at risk of sudden death when refeeding is started.

\section{Introduction}

Leucocytes from malnourished children have slow sodium pumps. Compared with values in children showing clinical recovery, the rate constant for sodium efflux is low, the glycosidesensitive sodium flux rate is diminished, the intracellular sodium concentration is raised, and the intracellular potassium concentration is decreased. ${ }^{2}$ This paper describes several malnourished children who did not show this pattern. Instead they had an

Tropical Metabolism Research Unit, University of the West Indies, Kingston, Jamaica

JOHN PATRICK, MD, MRCP, honorary consultant physician and Wellcome research fellow increased rate constant for sodium efflux and low intracellular sodium values. This group is at risk of sudden death during the start of high-energy feeding.

\section{Patients and methods}

Sodium pump activity in leucocytes was measured all the malnourished children when they were on a maintenance diet.

Measurements of sodium pump activity-The leucocytes were prepared and the rate constant for sodium efflux and intracellular sodium and potassium were measured as described. ${ }^{34}$ Intracellular sodium and potassium concentrations ( $\mathrm{mmol} / \mathrm{kg}$ of dry solids) can be measured more simply as follows. Leucocytes should be prepared by the dextran sedimentation method. ${ }^{3}$ The leucocytes should be washed with iso-osmolar magnesium chloride to remove extracellular sodium and potassium and the cell pellet dried, weighed, extracted in $0 \cdot 1-M$ nitric acid, and the sodium and potassium concentrations measured. Since the sodium and potassium ions and the dry weight in the final specimen are more than $95 \%$ intracellular, an extracellular fluid correction is unnecessary. These approximations lead to values within $5 \%$ of those obtained with an extracellular fluid correction.

Rehabilitation diet-This contained arachis oil $55 \mathrm{ml} / 1$ and a proprietary cows' milk formula, which provided $35 \mathrm{~g}$ protein and $5.6 \mathrm{MJ}(1350 \mathrm{kcal})$ per litre of feed. During rehabilitation the children were fed ad libitum and took $0 \cdot 5-1 \cdot 25 \mathrm{MJ} / \mathrm{kg} / 24 \mathrm{~h}(120-300 \mathrm{kcal} / \mathrm{kg} / 24$ h).

Four of the children died when high-energy feeding was started. Their pretreatment data were therefore analysed, and two other children with the same pattern of rate constants and sodium values were identified. They were monitored carefully when feeding began and successfully treated with diuretics and digoxin. The following case reports give brief details of the four children who died after the onset of high-energy feeding and more detailed histories of the two who showed the same syndrome but survived. Table I gives details of age, height, weight, and oedema recorded on admission to hospital. The diagnostic categories for the children are derived from the Wellcome classification. ${ }^{5}$

\section{CASE 1}

This child died suddenly on her sixth day in hospital, when she seemed to be recovering. No cause of death was found at necropsy. 
TABLE I-Anthropometric data and diagnostic category of six children who developed recovery syndrome

\begin{tabular}{|c|c|c|c|c|c|c|c|c|}
\hline $\begin{array}{l}\text { Case } \\
\text { No }\end{array}$ & $\begin{array}{c}\text { Age } \\
\text { (months) }\end{array}$ & Diagnosis & $\begin{array}{c}\text { Weight } \\
(\mathrm{kg})\end{array}$ & $\underset{\text { (cm) }}{\text { Height }}$ & $\begin{array}{l}\text { Weight } \\
\left(\begin{array}{c}\circ \text { standard } \\
\text { for age })\end{array}\right.\end{array}$ & $\begin{array}{l}\text { Height } \\
(\text { "o standard } \\
\text { for age) }\end{array}$ & $\begin{array}{c}\text { Weight } \\
\left(\begin{array}{c}\circ \\
\text { oftandard } \\
\text { for height })\end{array}\right.\end{array}$ & Oedema \\
\hline $\begin{array}{l}1 \\
2 \\
3 \\
4 \\
5 \\
6\end{array}$ & $\begin{array}{r}11 \\
20 \\
5 \\
28 \\
17 \\
14\end{array}$ & $\begin{array}{c}\text { Kwashiorkor } \\
\text { Marasmic kwashiorkor } \\
\text { Marasmus } \\
\text { Marasmic kwashiorkor } \\
\text { Marasmic kwashiorkor } \\
\text { Kwashiorkor }\end{array}$ & $\begin{array}{l}6 \cdot 85 \\
6 \cdot 46 \\
3 \cdot 34 \\
6 \cdot 00 \\
6 \cdot 35 \\
8 \cdot 30\end{array}$ & $\begin{array}{l}70 \cdot 5 \\
74 \cdot 5 \\
52 \cdot 0 \\
79 \cdot 00 \\
72 \cdot 00 \\
73 \cdot 5\end{array}$ & $\begin{array}{l}71 \\
55 \\
48 \\
46 \\
58 \\
80\end{array}$ & $\begin{array}{l}96 \\
89 \\
81 \\
88 \\
89 \\
95\end{array}$ & $\begin{array}{l}77 \\
66 \\
88 \\
56 \\
69 \\
86\end{array}$ & $\begin{array}{r}++ \\
++ \\
0 \\
++ \\
++ \\
++\end{array}$ \\
\hline
\end{tabular}

\section{CASE 2}

On the ninth day in hospital this child died suddenly. Before she died she had developed tachypnoea, tachycardia gallop rhythm, and diarrhoea. Necropsy showed a distended bowel and no other abnormalities except those associated with malnutrition.

\section{CASE 3}

On the eighth day in hospital this girl suffered a sudden cardiac arrest. In retrospect a brief antecedent tachypnoea was recognised.

\section{CASE 4}

This child died from persistent diarrhoea with gross abdominal distension and gastric dilatation on her seventh day in hospital. She had received potassium supplements of $30 \mathrm{mmol}(\mathrm{mEq}) /$ day and magnesium supplements of $15 \mathrm{mmol} /$ day $(30 \mathrm{mEq} /$ day).

\section{CASE 5}

This 17-month-old boy had had marasmic kwashiorkor, diarrhoea, vomiting, and cough for several months. Oedema had been present for a week. He had weighed $3200 \mathrm{~g}$ at birth. Subsequently he had received a very dilute formulation of a proprietary milk supplemented from 3 months of age with dilute cornmeal porridge from a bottle, occasional crushed vegetables, and herbal teas.

On examination the child was apathetic with red scanty hair, flaky dermatitis, dyspigmentation, and angular stomatitis. He had generalised oedema. His liver was not enlarged. He also had a left otitis media.

Treatment was started with milk feeds providing maintenance amounts of protein and energy and supplements of potassium, magnesium, iron, folic acid, and vitamins. Ampicillin was prescribed for the otitis media. Further investigations showed a urinary infection, pathogenic Escherichia coli, and strongyloides in the stool. A right upper lobe pneumonia subsequently proved to be tuberculous. The plasma albumin was $21 \mathrm{~g} / \mathrm{l}$. As these infections were diagnosed standard treatment was prescribed.

During the first week his condition slowly deteriorated-in particular, he became more apathetic and required feeding by nasogastric tube. On the eighth day in hospital his energy intake exceeded maintenance requirements and he was noted to be sitting up and more alert. On examination in the late afternoon, however, he was dyspnoeic with tachycardia, raised venous pressure, and a gallop rhythm. He rapidly became moribund, passed several watery stools in quick succession, while his abdomen became distended with visible peristalsis and a few high pitched bowel sounds. He was examined often during the day but bowel sounds were never absent. The diarrhoea and abdominal signs were the most prominent features, but because of the previous fatal cases he was treated with a single parenteral dose of frusemide $(10 \mathrm{mg})$ and digoxin $(0 \cdot 1 \mathrm{mg})$. The tachycardia and tachypnoea subsided over eight hours. In this acute episode he passed 13 watery stools in eight hours and lost $160 \mathrm{~g}$ in weight. Thereafter the stools again became normal in frequency and consistency. His subsequent recovery was slow but complete.

CASE 6

This 14-month-old girl presented with a history of having been unwell with intermittent diarrhoea and colds for three months. Over the few days before admission she had developed oedema. She had weighed $3900 \mathrm{~g}$ at birth, and she had been intermittently breast-fed for five months with supplements of dilute proprietary milk and dilute cornmeal porridge.

She looked extremely ill and apathetic with sparse thin red hair, generalised flaky dermatitis, angular stomatitis, and ulceration of the perineum. The mucous membranes were dry, yet she had gross generalised oedema. Her liver was palpable $4 \mathrm{~cm}$ below the costal margin. There was no evidence of infection. A chest radiograph showed nothing abnormal. Haemoglobin was $8 \cdot 1 \mathrm{~g} / \mathrm{dl}$, white cell count $8.9 \times 10^{9} / 1$, plasma sodium $140 \mathrm{mmol}(\mathrm{mEq}) / \mathrm{l}$, potassium $4.5 \mathrm{mmol}(\mathrm{mEq}) / \mathrm{l}$, and albumin $18.8 \mathrm{~g} / \mathrm{l}$.

She was treated initially with a diet providing maintenance amounts of energy and protein together with supplements of potassium, magnesium, iron, folic acid, and vitamins. On this regimen she lost all her oedema - a weight loss of $2 \cdot 1 \mathrm{~kg}\left(25 \cdot 3^{\circ}{ }_{0}\right.$ of her initial weight $)$ - in two weeks and her serum albumin rose to $21.4 \mathrm{~g} / \mathrm{l}$ (an amount compatible with the concentrating effect of loss of oedema). Her energy intake was increased above maintenance levels on the 14th day in hospital. Forty-eight hours later her respiratory rate rose from 30 to $70 / \mathrm{min}$ and her pulse rate from 120 to $160 / \mathrm{min}$. Venous pressure was also raised. She was given a single dose of digoxin and the respiratory rate fell to normal over 10 hours. The treatment had to be repeated 48 hours later, after which no further cardiovascular problems occurred. The child made a steady recovery thereafter apart from an episode of measles.

\section{Results}

Table II shows the results of the leucocyte tests performed before

TABLE II-Leucocyte electrolytes, rate constant for sodium efflux, and plasma electrolytes in children who developed recovery syndrome

\begin{tabular}{|c|c|c|c|c|c|c|c|c|c|c|c|}
\hline $\begin{array}{l}\text { Case } \\
\text { No }\end{array}$ & $\begin{array}{l}\text { Day of } \\
\text { study }\end{array}$ & $\begin{array}{l}\text { Day of } \\
\text { death or } \\
\text { recovery } \\
\text { syndrome }\end{array}$ & $\begin{array}{c}\text { Rate } \\
\text { constant } \\
\text { for sodium } \\
\text { efflux }\end{array}$ & $\begin{array}{l}\text { Sodium } \\
\text { efflux } \\
\text { rate } \\
(\mathrm{mmol} / \mathrm{l} / \mathrm{h})\end{array}$ & $\begin{array}{c}\text { Sodium } \\
\text { concentration } \\
\text { (mmol/1 cell } \\
\text { water) }\end{array}$ & $\begin{array}{c}\text { Sodium } \\
\text { content } \\
(\mathrm{mmol} / \mathrm{kg} \\
\text { dry solids) }\end{array}$ & $\begin{array}{c}\text { Potassium } \\
\text { concentration } \\
\text { (mmol/1 cell } \\
\text { water) }\end{array}$ & $\begin{array}{c}\text { Potassium } \\
\text { content } \\
\text { (mmol/kg } \\
\text { dry solids) }\end{array}$ & $\begin{array}{c}\text { Cell } \\
\text { water } \\
(1 / \mathrm{kg} \\
\text { dry solids) }\end{array}$ & $\begin{array}{l}\text { Plasma } \\
\text { sodium } \\
(\mathrm{mmol} / \mathrm{l})\end{array}$ & $\underset{\substack{\text { potassium } \\
(\mathrm{mmol} / \mathrm{l})}}{\text { Plasma }}$ \\
\hline $\begin{array}{l}1 \\
2 \\
3 \\
4 \\
5 \\
6\end{array}$ & $\begin{array}{c}3 \\
3 \\
2 \\
4 \\
1 \\
7 \\
9^{*} \\
1 \\
14 \\
19^{*}\end{array}$ & $\begin{array}{c}6 \\
9 \\
8 \\
7 \\
8\end{array}$ & $\begin{array}{l} \\
7.44 \\
5.57 \\
2.58 \\
3.75 \\
2.31 \\
4.41 \\
5.16 \\
2.73\end{array}$ & $\begin{array}{r}267 \\
206 \\
62 \\
152 \\
185 \\
40 \\
219 \\
248\end{array}$ & $\begin{array}{r}12 \\
38 \\
36 \\
37 \\
24 \\
41 \\
80 \\
9 \\
42 \\
91\end{array}$ & $\begin{array}{r}26 \\
81 \\
112 \\
95 \\
63 \\
91 \\
175 \\
18 \\
105 \\
291\end{array}$ & $\begin{array}{l}174 \\
165 \\
102 \\
171 \\
141 \\
169 \\
168 \\
180 \\
186 \\
123\end{array}$ & $\begin{array}{l}363 \\
348 \\
322 \\
444 \\
364 \\
373 \\
394 \\
377 \\
459 \\
394\end{array}$ & $\begin{array}{l}2.08 \\
2.11 \\
3.15 \\
2.59 \\
2.58 \\
2.21 \\
2.60 \\
2.09 \\
2.47 \\
3.20\end{array}$ & $\begin{array}{l}136 \\
140 \\
136 \\
127 \\
130 \\
130 \\
131 \\
135 \\
135 \\
133\end{array}$ & $\begin{array}{l}4 \cdot 6 \\
3.0 \\
5.2 \\
4.6 \\
4 \cdot 1 \\
4.5 \\
3.7 \\
4 \cdot 2 \\
4 \cdot 4 \\
4.3\end{array}$ \\
\hline
\end{tabular}


high-energy feeding in the six patients with acute extracellular fluid overload.

Table III shows the results in this group compared with those in the children who recovered uneventfully on high-energy feeding. The significances of the changes were assessed using both the $t$ test and the Mann-Whitney test. There was a highly significant difference in the values obtained for the changes in the rate constant and in the intracellular sodium values. Intracellular potassium concentrations were significantly different in the two groups when measured per unit of dry solids but not when measured per unit of cell water. This was largely because one of the children who died (case 3 ) had a very high cell water level for unknown reasons.

\section{Discussion}

This group of children who did not show the slow sodium pump in leucocytes that is usually associated with severe malnutrition were identified by retrospective analysis of pretreatment sodium transport measurements. After finding significant differences between the children who died and those who survived we predicted from their leucocyte sodium transport values that two other children would develop the syndrome. $\mathrm{W}^{\prime} \mathrm{e}$ therefore monitored them carefully and treated them successfully. Most children who die in hospital with protein energy malnutrition die within the first 48 hours, before refeeding has started. These children were at risk only after refeeding had started.

Once high-energy feeding had begun it took no longer than two hours for the children's condition to change from apparent cardiovascular normality to definite and life-threatening pulmonary congestion, with the additional features of watery diarrhoea and abdominal distension. It is unclear whether this syndrome develops only after treatment with an energy-dense oil-supplemented diet, but both the children who survived developed the syndrome within 48 hours of starting this rehabilitation diet. The respiratory and pulse rate often rose transiently in this period in the other four children, especially in those who presented with kwashiorkor. Even though marasmus is the more common form of malnutrition in Jamaica, five of the six children had an initial diagnosis of kwashiorkor. It is perhaps not surprising that patients who had been oedematous were more likely to develop an "overload" syndrome.

Cardiovascular problems during refeeding have been described before, though some of the features differ from the syndrome described here. In Uganda heart failure tended to occur in children with haemoglobin values below $7.0 \mathrm{~g} / \mathrm{dl}$ who had been receiving about $4.0 \mathrm{mmol}$ of sodium $/ \mathrm{kg}$ body weight $/$ day. ${ }^{6} \mathrm{~A}$ diet providing $1.0 \mathrm{mmol} / \mathrm{kg} /$ day was not associated with heart failure. The diet we used provided about $1 \cdot 0-1.5 \mathrm{mmol}$ sodium/ $\mathrm{kg} / \mathrm{day}$, and severe anaemia is not as common in Jamaica as in Uganda. .In some patients-for example, cases 2 and 4-we missed the preceding cardiorespiratory symptoms because we focused on the diarrhoea, which we treated with conventional fluid treatment for gastroenteritis. Diarrhoea occurred in several of these children, and in case 5 it disappeared as abruptly as it had begun. This abrupt onset and cessation remains unexplained.

Before we saw the development of the syndrome in cases 5 and 6 we discussed whether we should digitalise these children who were at risk of sudden death. It was argued that since the prognostic finding was a relatively fast sodium pump and normal intracellular electrolytes, digoxin would convert the cells to a more "normally malnourished" state-that is with a lower rate constant for sodium efflux and a higher intracellular sodium. We decided, however, that we should first observe carefully and avoid giving a potentially dangerous drug for entirely theoretical reasons. Once it was apparent that the syndrome was one of extracellular fluid overload digoxin and diuretics were given.

Unfortunately the yield of leucocytes in the last two children was small and it was therefore not possible to measure the oubain-insensitive proportion of transport. This does not invalidate the prognostic value of the measurements but it does make it difficult to discuss the effect on the energy-consuming portion of sodium transport. The effectiveness of the treatment and the reduction in the rate constant for sodium efflux after digoxin treatment suggest that the initial high rate constants were in fact largely the glycoside-sensitive portion.

The precise relation between the findings in the leucocyte and the development of this particular "recovery syndrome" is not clear. Malnourished children are at risk of pulmonary congestion for several reasons. Their cardiac outputs are low and renal function is impaired, ${ }^{7-9}$ but both these defects tend to recover in the first few days. The problem is to explain the origin of the sodium necessary to expand the extracellular space and the speed with which the syndrome develops. What we observed in the leucocyte studies during the maintenance period may have been the potential for recovery. The leucocyte studies are essentially in vitro because it takes about 70 minutes from collection before the final measurements can be made. During this time the cells are exposed to physiological saline and normal glucose concentrations. In this period low adenosine triphosphate (ATP) levels might be corrected. Garay and Garrahan $^{10}$ have shown in the red cell that low ATP levels depress the activity of the sodium pump, and ATP levels are known to be low in leucocytes obtained from malnourished children. ${ }^{11}$ The phenomenon we have observed is unlikely to be a basic cardiac problem, because the syndrome occurs as the cardiac features are resolving and it would not explain the other features of the syndrome such as the profuse diarrhoea and abdominal distension.

Whatever the physiological basis, it is important to be aware that these problems tend to occur in the first few days of rehabilitation with a high-energy intake. By carefully observing pulse and respiration rates it should be possible to start treatment appropriately. The sudden onset of watery diarrhoea at this stage of recovery does not necessarily indicate gastroenteritis. The clinician should try to measure the jugular venous pressure, and he should listen to the heart and lungs and see whether the liver is enlarged. If these signs suggest circulatory overload treatment should be started with digoxin and diuretics. It would be interesting to know whether the same syndrome occurs with parenteral feeding of malnourished adults secondary to other diseases or procedures. Reports of severe malnutrition include one example of sudden unexpected death during refeeding in an adult with anorexia nervosa ${ }^{12}$ and in the Minnesota study of starvation in initially normal men one subject developed sudden enlargement of the heart and increased venous pressure, which

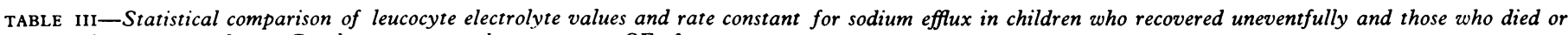
developed recovery syndrome. Results are expressed as means $\pm S E$ of mean

\begin{tabular}{|c|c|c|c|c|c|c|}
\hline & \multirow{2}{*}{$\begin{array}{c}\text { No of } \\
\text { patients }\end{array}$} & \multirow{2}{*}{$\begin{array}{l}\text { Total rate constant } \\
\text { for sodium efflux }\end{array}$} & \multicolumn{2}{|c|}{ Intracellular sodium } & \multicolumn{2}{|c|}{ Intracellular potassium } \\
\hline & & & $\begin{array}{l}\mathrm{mmol} / \mathrm{kg} \\
\mathrm{dry} \text { solids }\end{array}$ & $\begin{array}{c}\mathrm{mmol} / 1 \\
\text { cell water }\end{array}$ & $\begin{array}{l}\mathrm{mmol} / \mathrm{kg} \\
\mathrm{dry} \text { solids }\end{array}$ & $\begin{array}{c}\mathrm{mmol} / 1 \\
\text { cell water }\end{array}$ \\
\hline $\begin{array}{l}\text { Survivors } \\
\text { Children who died or } \\
\text { developed the recovery } \\
\text { syndrome }\end{array}$ & $\begin{array}{r}13 \\
4\end{array}$ & $\begin{array}{l}3 \cdot 72 \pm 0 \cdot 26 \\
5 \cdot 48 \pm 0 \cdot 76\end{array}$ & $\begin{array}{r}163 \pm 20 \\
85 \pm 12\end{array}$ & $\begin{array}{l}66 \cdot 8 \pm 6 \cdot 7 \\
34 \cdot 3 \pm 4 \cdot 6\end{array}$ & $\begin{array}{l}336+13 \\
384+22\end{array}$ & $\begin{array}{l}146 \pm 8 \cdot 1 \\
161 \pm 12 \cdot 2\end{array}$ \\
\hline $\begin{array}{l}\text { P value: } \\
t \text { test } \\
\text { Mann-Whitney test }\end{array}$ & & $\begin{array}{l}<0.025 \\
<0.01\end{array}$ & $\begin{array}{l}<0.025 \\
<0.01\end{array}$ & $\begin{array}{l}<0.01 \\
<0.01\end{array}$ & $\begin{array}{l}<0.05 \\
\text { NS }\end{array}$ & $\begin{array}{l}\text { NS } \\
\text { NS }\end{array}$ \\
\hline
\end{tabular}


responded to bed rest, diuretics, and reduced food intake. Unexpected death in malnourished children during refeeding has been reported many times. ${ }^{14-16}$

This work was supported by a grant from the Wellcome Trust.

\author{
References \\ 1 Patrick, J, Xth International Congress of Nutrition, Kyoto, Japan, 1975, \\ Abstract 3115. \\ 2 Patrick, J, and Golden, M N, American fournal of Clinical Nutrition. In \\ press. \\ 3 Patrick, J, and Hilton, P J, Clinical Science, 1973, 44, 457. \\ ${ }^{4}$ Hilton, P J, and Patrick, J, Clinical Science, 1973, 44, 439.
}

5 Wellcome Classification, Lancet, 1973, 2, 87.

6 Wharton, B A, Howells, G R, and MacCance, R A, Lancet, 1967, 2, 384.

- Alleyne, G A O, Clinical Science, 1966, 30, 553.

${ }^{8}$ Alleyne, G A O, Pediatrics, 1967, 39, 400.

9 Klahr, S, and Alleyne, G A O, Kidney International, 1975, 3, 129.

${ }^{10}$ Garay, R P, and Garahan, P J, Fournal of Physiology, 1975, 249, 51.

1 Yoshida, $T$, et al, Nature, 1967, 214, 525.

12 Berkman, J M, Weir, J F, and Kepler, E J, Gastroenterology, 1947, 35, 357.

${ }^{13}$ Simonson, E, Henschel, A, and Keys, A, American Heart fournal, 1948, 35, 584 .

14 Viteri, F, et al, in Mammalian Protein Metabolism, ed H N Munro and J B Allison, vol II, p 540. New York, Academic Press, 1964.

15 Smith, R, MD Thesis, Cambridge, 1960.

16 Smythe, P M, Swanepoel, A, and Campbell, J A H, British Medical fournal, 1962, 1, 67.

(Accepted 11 February 1977)

\title{
"Methicillin-resistant" Staphylococcus aureus: reassessment by controlled trial in burns unit
}

\author{
E J L LOWBURY, H A LILLY, A KIDSON
}

British Medical fournal, 1977, 1, 1054-1056

\section{Summary}

A controlled trial of oral flucloxacillin $(250 \mathrm{mg}$ six-hourly for four days) was performed in 34 patients treated by the covered method whose burns had yielded a heavy or moderate growth of Staphylococcus aureus resistant to methicillin at $30^{\circ} \mathrm{C}$ but moderately sensitive at $37^{\circ} \mathrm{C}$. Staph aureus was eliminated in nine of the 17 patients treated with flucloxacillin but in none of the 17 controls; the proportion of patients from whose burns sensitive Staph aureus was eliminated in an earlier trial of cloxacillin was greater than this. Strains of Staph aureus commonly described as methicillin-resistant and showing heterogeneous growth at $37^{\circ} \mathrm{C}$ of many sensitive and very few resistant bacterial cells should, in the light of these findings, be called moderately sensitive to flucloxacillin. Such "heteroresistant" strains showed consistent moderate sensitivity in replicate diffusion sensitivity tests at $37^{\circ} \mathrm{C}$, but very inconsistent results in replicate dilution tests, especially with flucloxacillin. These studies showed that 18-hour diffusion sensitivity tests indicate the clinical value of treatment with flucloxacillin for staphylococcal infections of moderate severity more correctly at $37^{\circ} \mathrm{C}$ than at $30^{\circ} \mathrm{C}$.

\section{Introduction}

Cultures of Staphylococcus aureus are usually tested for sensitivity to methicillin at $30^{\circ} \mathrm{C}$, because many strains that appear sensitive at $37^{\circ} \mathrm{C}$ are found to be resistant at $30^{\circ} \mathrm{C}$. The resistant cultures include a usually very large proportion of bacterial cells that are sensitive to methicillin at $37^{\circ} \mathrm{C}$ but resistant at $30^{\circ} \mathrm{C} .^{1-6}$

MRC Industrial Injuries and Burns Unit, Birmingham Accident Hospital, Birmingham B15 1NA

E J L LOWBURY, DM, FRCPATH, bacteriologist

H A LILLY, FIMLS, chief research officer

A KIDSON, FIMLS, chief medical laboratory scientist
As the site of infection is usually at or above the normal body temperature, the use of a test at a lower temperature $(30 \mathrm{C})$ is anomalous. Moreover, many "heteroresistant" strains of Staph aureus, which appear sensitive to methicillin when tested at $37^{\circ} \mathrm{C}$ but resistant when tested at $30^{\circ} \mathrm{C}$, seem, on diffusion tests, to be sensitive or relatively sensitive to cloxacillin and flucloxacillin at both $30^{\circ} \mathrm{C}$ and $37^{\circ} \mathrm{C}$. The irregularity of results on testing such strains for sensitivity to cloxacillin has led to the further anomaly of using methicillin as the sensitivity test agent when cloxacillin or flucloxacillin are the antibiotics used for treatment. ${ }^{\circ}$

Increasing proportions of Staph aureus isolated from burns in our unit $(57 \%$ in 1972) have been found to be resistant to methicillin when tested by a ditch plate diffusion test at $30^{\circ} \mathrm{C}$.? Controlled trials soon after the introduction of methicillin and cloxacillin showed that in about $80^{\circ}$ of patients sensitive strains of Staph aureus were eliminated from burn sites covered with dressings after a course of subcutaneous methicillin ${ }^{8}$ or five days' oral treatment with cloxacillin. ${ }^{9}$ To assess the clinical sensitivity or resistance of strains of Staph aureus described as methicillin-resistant by standard tests at $30^{\circ} \mathrm{C}$, we performed a controlled trial of oral flucloxacillin in patients whose burns were colonised by such staphylococci and were covered with dressings.

\section{Method}

The burns of patients in the burns unit were routinely examined ${ }^{10}$ for bacterial flora at every change of dressing. Strains of Staph aureus picked from horse blood agar plates and identified by a tube coagulase test were examined by a ditch plate test for their sensitivity to methicillin at $30^{\circ} \mathrm{C}$ and $37^{\circ} \mathrm{C}$, with $25 \mu \mathrm{g}$ of the antibiotic per ml of nutrient agar in the ditch. A few strains were also tested by a tube dilution method with methicillin and flucloxacillin at $30^{\circ} \mathrm{C}$ and $37^{\circ} \mathrm{C} ; 0.02 \mathrm{ml}$ of a 1/250 dilution of an overnight broth culture was used as the inoculum. They were also tested by a disc diffusion test, using Mast discs of methicillin $(10 \mu \mathrm{g})$ and flucloxacillin $(5 \mu \mathrm{g})$ at $30^{\circ} \mathrm{C}$ and at $37^{\circ} \mathrm{C}$ and a 1/250 dilution of an overnight broth culture as the plate inoculum. The tests were read after 18 hours' incubation; tests at $37^{\circ} \mathrm{C}$ were reincubated at $37^{\circ} \mathrm{C}$ and read again after 42 hours. The medium used for the tests was horse blood agar.

None of the patients studied had signs of clinical infection. Their burns were treated with dressings and were found to be heavily or moderately colonised with Staph aureus that was resistant to methicillin at $30^{\circ} \mathrm{C}$, as shown by growth across the ditch, and of reduced or 